\title{
Effect of Packaging and Cushioning Material Used During Road Transportation on Ripening Behavior and Storage of Alphonso Mango Fruits
}

\author{
Z.M. Burondkar*, C.D. Pawar, P.M. Haldankar, M.M. Burondkar, \\ P.B. Kardile, P.G. Borkar and J.S. Dhekale
}

\author{
College of Agriculture, Dr. Balasaheb Sawant Konkan Krishi Vidyapeeth, Dapoli, Dist \\ Ratnagiri, (M.S.)-415712, India
}

\begin{tabular}{|l|}
\hline Key w o r d s \\
Packaging, \\
Cushioning, \\
Alphonso mango \\
\hline Article Info \\
\hline $\begin{array}{l}\text { Accepted: } \\
\text { 20 April } 2018 \\
\text { Available Online: } \\
\text { 10 May } 2018\end{array}$ \\
\hline
\end{tabular}

\section{A B S T R A C T}

The present post-harvest investigation, aimed at studying the interaction effect of different packaging and cushioning material used during road transportation on physical properties of fruits during ripening and storage of Alphonso mango fruits, was undertaken at Department of Horticulture, College of Agriculture, Dapoli, during mango cropping season of 2013-14, in Factorial randomized block design (FRBD), with three replications. Fruit harvested at " $B$ " stage of physiological maturity, were packed in five different packaging materials (wooden box, bamboo basket (karandi), plastic crates, and corrugated fibre board boxes) and four cushioning materials (paddy straw, grass, tissue paper) followed by road transportation for $300 \mathrm{~km}$, were periodically assessed for different physical changes during ripening and storage. Result indicated that the weight, volume and specific gravity were more at harvest and all these characters decreased slightly at packing. There was (1.63\%) loss in fruit weight and $(2.11 \%)$ loss in fruit volume from time of harvest till time of packing, while specific gravity of fruits increased fractionally from (1.020 to 1.025), from harvest to packing. The earliest and maximum ripening of fruits at $7 \mathrm{DAP}$ was observed in treatment combination $\mathrm{P}_{1} \mathrm{C}_{1}$-Wooden box with paddy straw $(49.31 \%)$, followed by $\mathrm{P}_{4} \mathrm{C}_{3^{-}}$ CFB box with tissue paper (45.4\%), similarly minimum percent of green fruits $(6.25 \%$ and $9.03 \%)$ and minimum percent of diseased fruits $(2.11 \%$ and $2.23 \%)$ were also observed in above treatment combinations, respectively. Whereas minimum ripening percent $(9.72 \%)$, maximum percent of green fruits and diseased fruits percent $(38.19 \%$ and $15.97 \%$ respectively) was recorded in treatment combination $\mathrm{P}_{5} \mathrm{C}_{4^{-}}$i.e. loose fruits without cushioning material. At 14 DAP, when fruits were more critically viewed for shriveled and diseased fruits, the minimum percent of green shriveled $(2.39 \%$ and $2.47 \%)$ and half ripe shriveled $\left(4.65 \%\right.$ and $4.94 \%$ ) was recorded in $\mathrm{P}_{1} \mathrm{C}_{1}$-wooden box with paddy straw, followed by $\mathrm{P}_{4} \mathrm{C}_{3}$ - CFB box with tissue paper respectively.

\section{Introduction}

Mango (Mangifera indica L.) undoubtedly is one of the oldest and choicest fruits in the tropics and is acclaimed as "King" of fruits. It is the third widely produced fruit crop after banana and citrus, and occupy relatively the same position in the tropics as the apple in Europe and North America due to its wide adaptability, high nutritive value, richness in 
variety, delicious taste, pleasant flavour and attractive appearance. It enjoys the unique popularity among the masses and classes throughout the tropics.

Konkan region on the west coast of Maharashtra is emerging as one of the largest mango growing belts in the country, which comprises four mango growing districts viz., Thane (43492 ha), Raigad (47400 ha), Ratnagiri (63500 ha) and Sindhudurga (25494 ha), occupying 1.65 lakh ha of area under mango (Anon., 2012f). This region which occupies about 1 per cent of the total land area of the country, accounts for 7 per cent of the total area under mango in the country. Out of total area under mango in Konkan, more than 80 per cent is occupied by a single largest growing mango variety 'Alphonso', locally called as 'Hapus' with a major export share to the tune of over 30 per cent. But mango is perishable in nature and there are many occasions for it to get spoiled till the fruit reaches consumer's table. Spoilage of fruit is the bottleneck problem of meagre export of Alphonso mangoes though its production is very large. The principle causes for postharvest losses are by infections of pathogens, rough handling, improper packaging, improper mode of transportation and unhygienic storage conditions. It is estimated that the total losses due to spoilage may be nearly 20-30 per cent of fruit harvest.As far packaging is concerned, up till now the wooden boxes, bamboo baskets and CFB boxes are most commonly used in all over India for mangoes. But the pioneer work has done by Joshi and Roy (1985) on corrugated fibre board boxes for packaging of Alphonso mangoes now leads to an effective alternative packaging material for mangoes.

In the view of all these, the present study on "Effect of different packaging and cushioning material on quality and shelf life of mango (Mangifera indica L.) fruits Cv. Alphonso was conducted with objective to find out best packagingand cushioning material material for optimum ripening and quality of Alphonso mangoes.

\section{Materials and Methods}

The present investigation on Effect of different packaging and cushioning material on quality and shelf life of mango (Mangifera indica L.) Fruits Cv. Alphonso was undertaken in Department of Horticulture, College of Agriculture, Dapoli during mango cropping season of 2013-14 and it was conducted in FRBD with three replications, During the investigation, major emphasis was given on studying the effect of different packaging material in combination with different cushioning material on changes in physical parameters, ripening pattern, shrivelling, spoilage and shelf life of Alphonso mango fruits during packaging and ripening. Alphonso mangoes were obtained from orchard of Department of Horticulture, College of Agriculture, Dapoli (M.S) India. Fruits were harvested by Nutan mango nipper in early morning hours. These harvested mangoes were then taken to packing house. At the packing house all the harvested mangoes were checked for their full maturity carefully which was done by dipping them in water at ambient temperature. The fruits which sunk in water (specific gravity >1.0) were selected for experiment and the fruits which floated were discarded. care was taken that no diseased, deformed or immature fruits were selected to carry out experiment. A total number of 2880 Alphonso mango fruits were selected.To study effect of packaging and cushioning material, the wooden box, bamboo basket (karandi), plastic crates, and corrugated fibre board boxes were used as a packaging material and paddy straw, grass, tissue paper was used as cushioning material. All these materials were procured from local market and university far. In order to examine effect of different packaging and cushioning treatments on brusing and impact damage which normally occur to fruit during long distance road 
transportation, further all the packed fruits in their respective packaging and cushioning material were loaded in a mini truck and these fruits were transported from dapolito Ratnagiri and back to Dapoli (total 300 kilometers on same day of packaging and were moved to storage room).

Table.1 Number of treatment combinations: twenty (20) as below

\begin{tabular}{|c|c|l|} 
Sr. No. & $\begin{array}{c}\text { Treatment } \\
\text { No. }\end{array}$ & \multicolumn{1}{|c}{ Packaging and cushioning material used } \\
\hline $\mathbf{1}$ & $\mathbf{P}_{\mathbf{1}} \mathbf{C}_{\mathbf{1}}$ & Wooden box with paddy straw \\
\hline $\mathbf{2}$ & $\mathbf{P}_{\mathbf{1}} \mathbf{C}_{\mathbf{2}}$ & Wooden box with dry grass \\
\hline $\mathbf{3}$ & $\mathbf{P}_{\mathbf{1}} \mathbf{C}_{\mathbf{3}}$ & Wooden box with tissue paper \\
\hline $\mathbf{4}$ & $\mathbf{P}_{\mathbf{1}} \mathbf{C}_{\mathbf{4}}$ & Wooden box without cushioning material \\
\hline $\mathbf{5}$ & $\mathbf{P}_{\mathbf{2}} \mathbf{C}_{\mathbf{1}}$ & Bamboo basket (karandi) with paddy straw \\
\hline $\mathbf{6}$ & $\mathbf{P}_{\mathbf{2}} \mathbf{C}_{\mathbf{2}}$ & Bamboo basket (karandi) as cushioning material with dry grass \\
\hline $\mathbf{7}$ & $\mathbf{P}_{\mathbf{2}} \mathbf{C}_{\mathbf{3}}$ & Bamboo basket (karandi) with tissue paper \\
\hline $\mathbf{8}$ & $\mathbf{P}_{\mathbf{2}} \mathbf{C}_{\mathbf{4}}$ & Bamboo basket (karandi) without cushioning material \\
\hline $\mathbf{9}$ & $\mathbf{P}_{\mathbf{3}} \mathbf{C}_{\mathbf{1}}$ & Plastic crate with paddy straw \\
\hline 10 & $\mathbf{P}_{\mathbf{3}} \mathbf{C}_{\mathbf{2}}$ & Plastic crate with dry grass \\
\hline 11 & $\mathbf{P}_{\mathbf{3}} \mathbf{C}_{\mathbf{3}}$ & Plastic crate with tissue paper \\
\hline 12 & $\mathbf{P}_{\mathbf{3}} \mathbf{C}_{\mathbf{4}}$ & Plastic crate without cushioning material \\
\hline 13 & $\mathbf{P}_{\mathbf{4}} \mathbf{C}_{\mathbf{1}}$ & Corrugated fibre board box with paddy straw \\
\hline 14 & $\mathbf{P}_{\mathbf{4}} \mathbf{C}_{\mathbf{2}}$ & Corrugated fibre board box with dry grass \\
\hline 15 & $\mathbf{P}_{\mathbf{4}} \mathbf{C}_{\mathbf{3}}$ & Corrugated fibre board box with tissue paper \\
\hline 16 & $\mathbf{P}_{\mathbf{4}} \mathbf{C}_{\mathbf{4}}$ & Corrugated fibre board box without cushioning material \\
\hline 17 & $\mathbf{P}_{\mathbf{5}} \mathbf{C}_{\mathbf{1}}$ & Loose fruits with paddy straw \\
\hline 18 & $\mathbf{P}_{\mathbf{5}} \mathbf{C}_{\mathbf{2}}$ & Loose fruits with dry grass \\
\hline 19 & $\mathbf{P}_{\mathbf{5}} \mathbf{C}_{\mathbf{3}}$ & Individual fruit wrappedin tissue paper \\
\hline $\mathbf{2 0}$ & $\mathbf{P}_{\mathbf{5}} \mathbf{C}_{\mathbf{4}}$ & Loose fruits without cushioning material \\
\hline & & \\
\hline
\end{tabular}

\section{Experimental design}

No. of replications

No. of fruits per treatment per replication

Total No. of fruits studied
Factorial RBD

Three

48

2880

\section{Results and Discussion}

The results of the investigation are presented and discussed in this chapter under the following subheads.

Effect of packaging and cushioning material on changes in physical characteristics of Alphonso mango fruits during storage.

\section{Weight of fruit}

The periodical data regarding weight of Alphonso mango fruits illustrated in figure 1. It was revealed that at $7 \mathrm{DAP}$, irrespective of cushioning material used; all the packaging materials significantly influenced the weight. Among the five packaging materials, $\mathrm{P}_{4}-\mathrm{CFB}$ box $(27.30 \mathrm{~g})$, registered significantly less drop 
in fruit weight; whereas significantly highest drop in weight was observed in $\mathrm{P}_{5}$-loose fruits (35.41g). Similar trend continued till 14DAP. As minimum loss in weight was recorded again by P4- CFB Box (48.98g), followed by $\mathrm{P}_{1}$-wooden box $(49.76 \mathrm{~g})$, which were at par with each other. This could be attributed to higher loss of moisture with early onset of hydrolytic processes and respiration, which may lead to inevitable loss in weight (Lee et al., 1995; Giovannoni, 2001; Wills et al., 2007). Amongst the four methods adopted, the weight loss at 7 DAP was significantly lowest in $\mathrm{C}_{1}$-Paddy straw (28.99g), followed by $\mathrm{C}_{3}$ Tissue paper (29.46g), which were at par with each other. Whereas the significantly highest weight loss (34.53 g) was noted in $\mathrm{C}_{4}$-loose fruits. At 14 DAP, maximum loss in weight was observed in $\mathrm{C}_{4}$-fruits without cushioning material $(58.27 \mathrm{~g})$ whereas significantly lower loss in weight was noticed in $\mathrm{C}_{3}$-tissue paper (46.76g), followed by $\mathrm{C}_{1^{-}}$paddy straw (48.01g) which were at par with each other.

\section{Packaging X Cushioning}

At 14 DAP, among all treatment combinations tried, significantly lower weight loss of fruit (42.32g) was recorded in $\mathrm{P}_{4} \mathrm{C}_{3}-\mathrm{CFB}$ box with tissue paper, followed by $\mathrm{P}_{1} \mathrm{C}_{1}$-Wooden box with paddy straw $(44.22 \mathrm{~g}), \mathrm{P}_{3} \mathrm{C}_{1}$ - plastic crate with paddy straw $(46.09 \mathrm{~g}), \mathrm{P}_{2} \mathrm{C}_{1}-$ bamboo basket with paddy straw (46.82g), and $\mathrm{P}_{2} \mathrm{C}_{3^{-}}$ bamboo basket with tissue paper (47.03g). Whereas, maximum loss was recorded in $\mathrm{P}_{5} \mathrm{C}_{4}$ - loose fruits without cushioning material $(65.25 \mathrm{~g})$ which may be attributed to inevitable loss in weight under the influence of higher transpiration and respiration (Lee et al., 1995; Giovannoni, 2001; Wills et al., 2007).

\section{Volume of fruit}

At 7 DAP; irrespective of cushioning material used, all the packaging materials significantly influenced the fruit volume. Among the five packaging materials, $\mathrm{P}_{4}$-CFB box $(10.63 \mathrm{ml})$, registered significantly less drop in volume loss, followed by $\mathrm{P}_{2}$-bamboo basket (12.19 $\mathrm{ml})$ and $\mathrm{P}_{1^{-}}$wooden box $(12.22 \mathrm{ml})$, which were at par with each other. Whereas significantly the highest volume loss was reported in $\mathrm{P}_{4}$-loose fruits $(14.55 \mathrm{ml})$, which may be attributed to facilitation for higher transpiration and respiration, which may lead to inevitable loss in volume (Lee et al., 1995; Giovannoni, 2001; Wills et al., 2007). At 14 DAP also, $\mathrm{P}_{4}$ - CFB box recorded significantly lowest loss in volume $(48.07 \mathrm{ml})$, followed by $\mathrm{P}_{1}$ - wooden box $(48.83 \mathrm{ml})$, which were at par with each other. Whereas significantly maximum loss in fruit volume was observed in $\mathrm{P}_{5^{-}}$loose fruits $(52.35 \mathrm{ml})$. At 14 DAP, the loss in fruit volume was observed to be significantly minimum in $\mathrm{C}_{3^{-}}$tissue paper (45.89 $\mathrm{ml}$ ), followed by $\mathrm{C}_{1^{-}}$paddy straw $(47.12 \mathrm{ml})$ which were at par with each other whereas, significantly maximum volume loss was observed in $\mathrm{C}_{4}$-loose fruits without cushioning material $(57.19 \mathrm{ml})$. These results are in accordance with those reported earlier by Padhye (1997) and Anila et al., (2003) in Cv. Alphonso.

\section{Packaging X Cushioning}

At 14 DAP, $\mathrm{P}_{5} \mathrm{C}_{4}$-loose fruits without cushioning material $(64.03 \mathrm{ml})$ recorded significantly maximum loss in volume; whereas minimum volume loss were reported in $\mathrm{P}_{4} \mathrm{C}_{3}$-CFB box with tissue paper (41.53 ml), followed by $\mathrm{P}_{1} \mathrm{C}_{1}$ - wooden box with paddy straw $(43.40 \mathrm{ml}), \mathrm{P}_{3} \mathrm{C}_{1^{-}}$plastic crate with paddy straw (45.23 ml), $\mathrm{P}_{5} \mathrm{C}_{3}$-loose fruits with tissue paper $(12.07 \mathrm{ml}), \mathrm{P}_{2} \mathrm{C}_{1}$ - bamboo basket with paddy straw (45.95 ml), $\mathrm{P}_{2} \mathrm{C}_{3}$ and $\mathrm{P}_{5} \mathrm{C}_{3}$ which were all at par with each other. Similar trend in volume loss of mango fruits under influence of packaging and cushioning material was also reported by Padhye (1997) in Alphonso mangoes, Carrillo-Lopez et al., (2000) in Cv. Haden, and Masalkar et al., 
(2006) and Mane (2013) in Cv. Alphonso. Continuously higher relative humidity around fruits in CFB boxes which substantially inhibit transpiration losses, could have contributed for observing minimum loss in volume and weight of mango fruits as also reported earlier by Padhye (1997) in Alphonso mangoes Carrillo-Lopez et al., (2000) in Cv. Haden, Masalkar et al., (2006) and Mane (2013) in Cv. Alphonso.

\section{Physiological loss in weight (\%) (PLW)}

The data further revealed that, at 7 DAP, irrespective of cushioning material used; all the packaging material significantly influenced the PLW. Among the five packaging material, $\mathrm{P}_{4}$-CFB box registered significantly lowest PLW (10.83\%). Whereas, significantly the highest PLW (14.83\%) was found in $\mathrm{P}_{5}$-loose fruits. At $14 \mathrm{DAP}$, following the same trend, significantly the lowest PLW was observed in $\mathrm{P}_{4}$-CFB Boxes (17.95\%); whereas maximum PLW was recorded in $\mathrm{P}_{5^{-}}$ loose fruits $(22.42 \%)$.

The similar trend of lowest PLW due to $\mathrm{P}_{4-}$ CFB boxes was also reported earlier by Pandey and Singh (2007), Rathore et al., (2007) and Tefera et al., (2007). The low PLW under tissue paper $\left(\mathrm{C}_{3}\right)$ and paddy straw $\left(\mathrm{C}_{1}\right)$ could be attributed to high surface humidity around the fruits that might have slowed down the rate of transpiration and respiration (Verma, 2012).

Similar trend of PLW was followed till 14 DAP as significantly the lowest PLW was recorded in $\mathrm{C}_{3}$-tissue paper $(17.89 \%)$ and significantly maximum PLW was noticed in $\mathrm{C}_{4}$-fruits without cushioning material (23.89\%).

\section{Packaging X Cushioning}

Significantly lower PLW (9.02 \%) was recorded in $\mathrm{P}_{4} \mathrm{C}_{3}$-CFB box with tissue paper, which was closely followed by $\mathrm{P}_{1} \mathrm{C}_{1}$-wooden box with paddy straw (10.32\%), $\mathrm{P}_{4} \mathrm{C}_{1}-\mathrm{CFB}$ box with paddy straw $(10.56 \%), \quad \mathrm{P}_{4} \mathrm{C}_{4}{ }^{-}$ Corrugated fibre board box without cushioning material and $\mathrm{P}_{1} \mathrm{C}_{2^{-}}$wooden box with dry grass $(10.74 \%)$, which were at par with each other. Whereas, significantly higher PLW was noticed in $\mathrm{P}_{5} \mathrm{C}_{4}$-loose fruits without cushioning material which was as high as $(15.95 \%)$.

At 14 DAP also, minimum PLW was recorded in $\mathrm{P}_{4} \mathrm{C}_{3}-\mathrm{CFB}$ box with tissue paper (14.02\%), followed by $\mathrm{P}_{1} \mathrm{C}_{1}$-Wooden box with paddy straw $(15.65 \%)$, which were at par with each other. Whereas, significantly maximum PLW was found in $\mathrm{P}_{5} \mathrm{C}_{4}$-Loose fruits without any cushioning material (25.33\%). These results are in accordance with those reported by Pandey and Singh (2007) in mango, Rathore et al., (2007) in Cv. Dashehari and Tefera et al., (2007) in Cv. Baneshan.

\section{Colour of fruit}

The chromacity value of change in fruit skin colour in terms of "L", "a" and "b" was measured at 0,7 and 14 DAP is presented in Table 1. The significant difference in all values was recorded in all treatment combinations only at $7^{\text {th }}$ day, as discussed here under.

\section{Lightness " $L$ " value}

The chroma value "L" indicates lightness which extends from 0 (black) to 100 (white). Irrespective of packaging and cushioning material used, the Chroma value "L" increased rapidly from 0 days (42.16) to 7 days of packaging (48.19) and then increased slightly from 7 days of packaging up to 14 days of storage (48.34). 

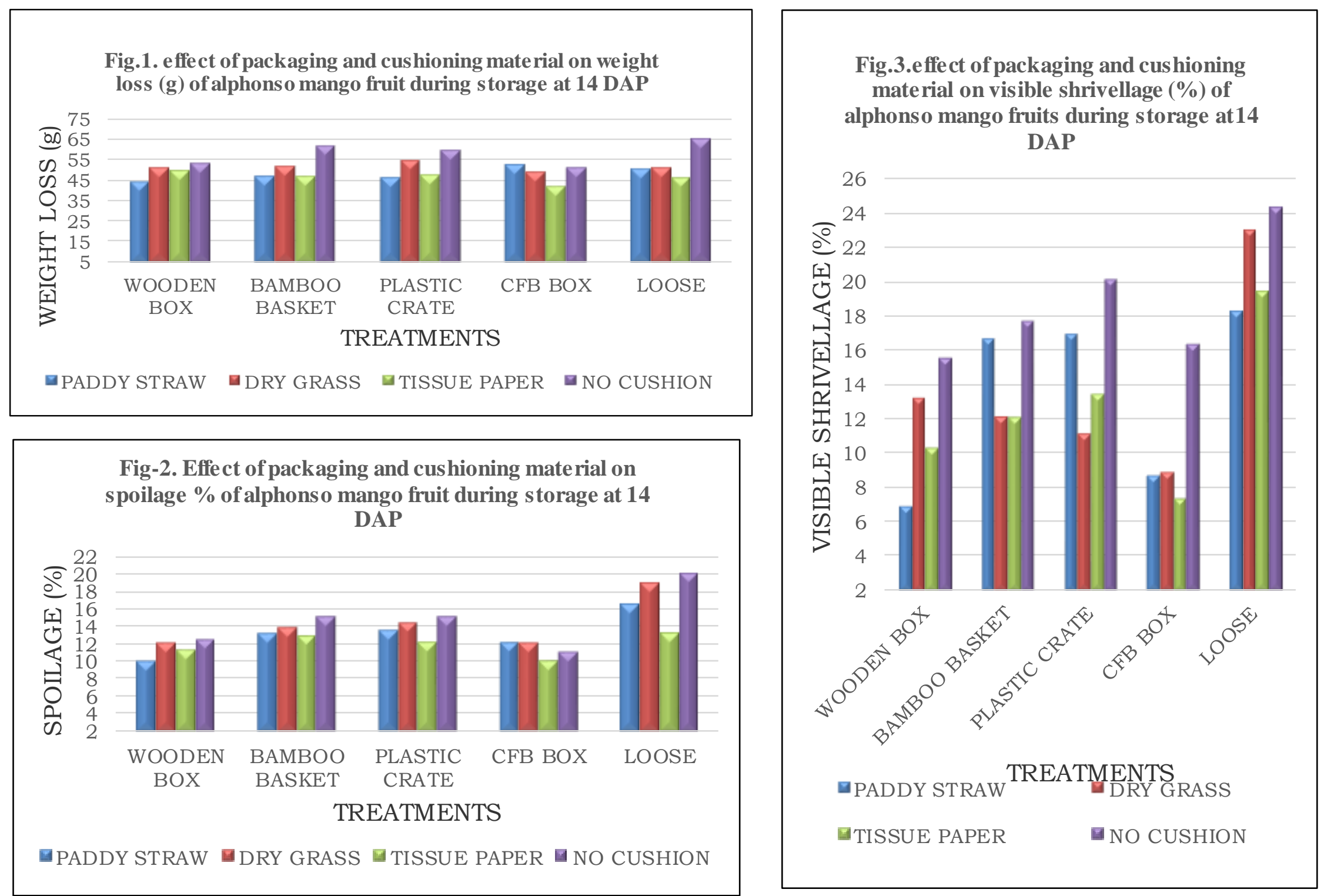
Table.2 Effect of packaging and cushioning material on chroma value "b" of colour on Alphonso mango fruits during storage

\begin{tabular}{|c|c|c|c|c|c|c|c|c|c|c|c|c|c|c|c|}
\hline \multirow[t]{3}{*}{ TREATMENTS } & \multicolumn{5}{|c|}{ O DAYS } & \multicolumn{5}{|c|}{7 DAYS } & \multicolumn{5}{|c|}{14 DAYS } \\
\hline & \multicolumn{5}{|c|}{ "b" value } & \multicolumn{5}{|c|}{ "b" value } & \multicolumn{5}{|c|}{ "b" value } \\
\hline & C1 & $\mathrm{C} 2$ & C3 & C4 & MEAN & C1 & $\mathrm{C} 2$ & C3 & C4 & MEAN & C1 & $\mathrm{C} 2$ & C3 & C4 & MEAN \\
\hline$\overline{\mathbf{P 1}}$ & 17.86 & 17.89 & 17.47 & 17.85 & 17.77 & 30.44 & 25.72 & 27.44 & 23.72 & 26.83 & 24.27 & 26.18 & 24.43 & 24.45 & 24.83 \\
\hline $\mathbf{P 2}$ & 17.65 & 17.48 & 17.57 & 17.31 & 17.50 & 24.67 & 25.58 & 26.40 & 23.83 & 25.12 & 24.45 & 24.22 & 24.45 & 24.27 & 24.35 \\
\hline $\mathbf{P 3}$ & 17.46 & 18.00 & 16.48 & 17.19 & 17.28 & 24.72 & 23.33 & 26.87 & 21.67 & 24.15 & 24.45 & 24.22 & 24.27 & 24.31 & 24.31 \\
\hline $\mathbf{P 4}$ & 17.04 & 17.11 & 17.45 & 17.73 & 17.33 & 26.87 & 26.50 & 29.11 & 25.94 & 27.11 & 24.31 & 23.73 & 24.31 & 24.22 & 24.14 \\
\hline $\mathbf{P 5}$ & 18.34 & 18.45 & 16.73 & 17.71 & 17.81 & 25.12 & 26.31 & 25.11 & 19.63 & 24.04 & 24.21 & 24.31 & 24.27 & 24.27 & 24.26 \\
\hline Mean & 17.67 & 17.79 & 17.14 & 17.56 & 17.54 & 26.36 & 25.49 & 26.99 & 22.96 & 25.45 & 24.34 & 24.53 & 24.34 & 24.30 & 24.38 \\
\hline $\begin{array}{l}\text { Source of } \\
\text { variation }\end{array}$ & $\mathrm{SE} \pm$ & & & D at 5 & & $\mathrm{SE} \pm$ & & CD & at $5 \%$ & & SE \pm & & & D at $5 \%$ & \\
\hline Packaging (P) & 0.206 & & & NS) & & 0.458 & & 1.3 & 11 & & 0.227 & & & NS) & \\
\hline Cushioning (C) & 0.184 & & & NS) & & 0.410 & & 1.1 & 73 & & 0.203 & & & NS) & \\
\hline Interaction (PXC) & 0.412 & & & VS) & & 0.916 & & 2.6 & 22 & & 0.455 & & & NS) & \\
\hline $\begin{array}{l}\mathrm{P}_{1} \text { : Wooden box } \\
\mathrm{C}_{1} \text { : Paddy straw }\end{array}$ & & $\begin{array}{l}\text { : Bambo } \\
: \text { Grass }\end{array}$ & basket & & $\begin{array}{l}\text { Plastic crat } \\
\text { Tissue pape }\end{array}$ & & $\begin{array}{l}\mathrm{P}_{4}: \mathrm{CFH} \\
\mathrm{C}_{4}: \text { Fru }\end{array}$ & $\begin{array}{l}3 \text { box } \\
\text { its withou }\end{array}$ & at cushion & ing materia & & Loose & & & \\
\hline
\end{tabular}




\section{Packaging X Cushioning}

At 7 DAP, chroma value "L" was significantly influenced by the interaction of packaging and cushioning conditions. Among the different treatment combinations tried, fruits ripened in $\mathrm{P}_{1} \mathrm{C}_{1}$-Wooden box with paddy straw (53.97), $\mathrm{P}_{4} \mathrm{C}_{3}$-CFB box with tissue paper (51.85), $\mathrm{P}_{4} \mathrm{C}_{1}-\mathrm{CFB}$ box with paddy straw (51.81), which were at par with each other, significantly had sharp colour brightness owing to high Chroma value "L". Whereas, significantly lowest Chroma value "L" was observed in $\mathrm{P}_{5} \mathrm{C}_{4}$-Loose fruits without any cushioning material (41.40).

At 14 DAP, irrespective of packaging and cushioning material used, differences in Chroma value "L" were non-significant among all treatment combinations.

\section{Greenness to redness "a" value}

The chroma value "a" indicates turning fruits from greenness to redness. Positive (+ve) values indicate that fruits are turning towards redness; while negative (-ve) values indicate fruits turning towards greenness. The data regarding influence of packaging materials and different cushioning materials on change in chroma value "a" during 0 to 7 DAP and 7 to 14 DAP. Data indicated that all the treatments significantly differed for chroma value "a" only at 7 DAP, and values ranged from (-4.51) at 0 days to (12.60) at 14 DAP, irrespective of packaging and cushioning material used.

\section{Packaging X Cushioning}

Chroma value "a" was significantly influenced by the interaction of packaging and cushioning conditions at 7DAP.

Among different treatment combination tried, fruits ripened in $\mathrm{P}_{1} \mathrm{C}_{1}$-wooden box with paddy straw (11.34), $\mathrm{P}_{4} \mathrm{C}_{3}-\mathrm{CFB}$ box with tissue paper (10.47), $\mathrm{P}_{4} \mathrm{C}_{1}-\mathrm{CFB}$ box with paddy straw (9.90), $\mathrm{P}_{5} \mathrm{C}_{3}$ - loose fruits with tissue paper (9.64), and $\mathrm{P}_{1} \mathrm{C}_{2}$-Wooden box with grass (9.08), $\quad \mathrm{P}_{4} \mathrm{C}_{4}-\mathrm{CFB}$ box without cushioning material (8.64) which were at par with each other had significantly higher Chroma value "a".

\section{Blueness to yellowness " $b$ " value}

The data on influence of various packaging materials and different cushioning materials on colour intensification in terms of chroma value "b" of fruits, recorded at 0,7 and 14 DAP Presented in Table 1. It could be observed from the data that, irrespective of packaging and cushioning material used, the Chroma value " $b$ " were positive and increased from 0 days (17.54) to 7 DAP (25.45) and then decreased till 14 DAP (24.38).

This indicated that fruits under any treatment never had blue colour in the skin but had varying degree of yellowness which was significantly noticed at 7 DAP.

\section{Packaging X Cushioning}

Chroma value " $b$ " recorded at 7 DAP, was found to significantly influence by the interaction of packaging and cushioning material. Among the all treatment combinations tried, significantly highest intensification of yellowness as measured in terms of chroma value " $b$ ", was recorded in $\mathrm{P}_{1} \mathrm{C}_{1}$-wooden box with paddy $\operatorname{straw}(30.44)$, followed by $\mathrm{P}_{4} \mathrm{C}_{3}$-CFB box with tissue paper (29.11), which were at par with each other; whereas, significantly lower Chroma value "b" was noticed in $\mathrm{P}_{5} \mathrm{C}_{4}$-Loose fruits without cushioning material (19.63).

At 14 DAP, no significant differences were observed regarding chroma value " $b$ ", in all treatment combinations which becomes visible with advancement of ripening (Kays, 
1999; Niemann, 2005; Wills et al., 2007). The similar trend in the colour change during the ripening was also observed by Cocozza et al., (2004) in Cv. Tommy Atkins, Singh et al., (2008) in Cvs. Chausa, Langra and Dashehari, Mane (2013) in Cv. Alphonso and Zaharah and Singh (2013) in Cv. Kensington Pride (Table 2).

\section{Visible shrivellage (\%)}

The periodical data regarding shrivellage of Alphonso mango fruits as influenced by various packaging materials and different cushioning materials are illustrated in figure 3 . This revealed that none of the treatments developed any sign of shrivellage till 7 DAP, but visible and significant differences among the treatments for percent shrivellage were observed after 14DAP.

\section{Packaging X Cushioning}

Data on fruit shrivellage, as observed at 14 DAP, was found significantly influenced by the interaction of packaging and cushioning conditions. Among the different treatment combinations, significantly lower shrivellage of fruits was recorded in $\mathrm{P}_{1} \mathrm{C}_{1}$-Wooden box with paddy straw $(6.97 \%)$, followed by $\mathrm{P}_{4} \mathrm{C}_{3}$ CFB box with tissue paper $(7.41 \%), \mathrm{P}_{4} \mathrm{C}_{1-}$ CFB box with paddy straw $(8.73 \%)$ and $\mathrm{P}_{4} \mathrm{C}_{2-}$ CFB box with dry grass $(8.90 \%)$, which all were at par with each other. Whereas, significantly higher shrivellage was observed in $\mathrm{P}_{5} \mathrm{C}_{4}$-Loose fruits without cushioning material $(24.30 \%)$. Same type of observations also reported by Laxminarayana et al., (1974), Joshi (1983), Padhye (1997) and Mane (2013).

\section{Spoilage (\%)}

The periodical data regarding spoilage of Alphonso mango fruits as influenced by various packaging material and different cushioning material (Fig. 2).

\section{Packaging X Cushioning}

Perusal of data regarding spoilage of fruits at 7 DAP indicated that percent spoilage of fruits was significantly influenced by the interaction of packaging and cushioning conditions. A maximum spoilage was noticed in $\mathrm{P}_{5} \mathrm{C}_{4}$-Loose fruits without cushioning material (15.97\%), whereas it was meager in $\mathrm{P}_{1} \mathrm{C}_{1}$-Wooden box with paddy straw $(2.11 \%)$ and $\mathrm{P}_{4} \mathrm{C}_{3}-\mathrm{CFB}$ box with tissue paper $(2.23 \%)$ which was at par with each other. Similar trend was observed at $14 \mathrm{DAP}$ as maximum spoilage percentage was recorded in $\mathrm{P}_{5} \mathrm{C}_{4}{ }^{-}$ loose fruits without cushioning material (20.14\%) and minimum spoilage percentage was observed in $\mathrm{P}_{1} \mathrm{C}_{1}$-wooden box with paddy straw $(10.11 \%)$ followed by $\mathrm{P}_{4} \mathrm{C}_{3}-\mathrm{CFB}$ box with tissue paper $(10.12 \%)$, which were at par with each other. Efficacy of CFB box as packing material and tissue paper as cushioning material in reducing the spoilage percentage during ripening and storage of mangoes was earlier reported by Padhye (1997) in Alphonso mangoes Carrillo-Lopez et al., (2000) in Cv. Haden, Masalkar et al., (2006) and Mane (2013) in Cv. Alphonso.

\section{Shelf-life}

Data further revealed that fruit shelf life was significantly influenced by the interaction of packaging and cushioning conditions.

\section{Packaging X Cushioning}

Among the all treatment combinations, at 14 DAP significantly maximum shelf life at 14 DAP with minimum spoilage was observed in $\mathrm{P}_{1} \mathrm{C}_{1}$-Wooden box with paddy straw $(10.11 \%)$ followed by $\mathrm{P}_{4} \mathrm{C}_{3}-\mathrm{CFB}$ box with tissue paper $(10.12 \%)$ as its spoilage was less than the average spoilage of 12 per cent.

Following results regarding better shelf life of packed fruits and minimum shelf life of 
unpacked fruits was earlier reported by Padhye (1997) in Alphonso mangoes CarrilloLopez et al., (2000) in Cv. Haden, Masalkar et al., (2006) and Mane (2013) in Cv. Alphonso.

From the present investigation, it could be concluded that:

Amongst the 4 types of packaging material evaluated, CFB boxes $\left(\mathrm{P}_{4}\right)$, proved to be more efficient and found widely more compatible with different cushioning materials used than any other packaging material; whereas; among three types of cushionings, tissue paper $\left(\mathrm{C}_{3}\right)$ and paddy straw $\left(\mathrm{C}_{1}\right)$ found equally good and compatible with different packaging materials for realising better fruit quality and shelf life of ripe Alphonso mango fruits.

Handling fruits loose $\left(\mathrm{P}_{5} \mathrm{C}_{4}\right)$ during distant transportation and ripening, found most inadvisable practice, as this not only adversely affected course of normal ripening and final fruit quality of ripe fruits, but also caused heavy PLW, shrivellage, and spoilage of fruits, leading to severe reduction in the shelf-life of fruits.

\section{References}

Anila R. and T. Radha (2003). Physicochemical analysis of mango varieties under Kerala condition. J. Trop. Agril., 41 (2003): 20-22.

Cocozza, F. M., Jorge, J. T., Alves, R. E., Filgueiras, H. A. C., DSantos and M. E. C. Pereira (2004). Sensory and physical evaluations of cold stored 'Tommy Atkins' mangoes influenced by 1 - MCP and modified atmosphere packaging. Acta Hort., p.645.

Giovannoni, J. (2001). Molecular biology of fruit maturation and ripening.Pl. Mol. Biol., 52: 725-749.
Joshi, G. D. and Roy, S. K. (1985). Effect of integrated post-harvest handling on biochemical changes in Alphonso mango fruits. Prog. Hort., 17(1): 56-63.

Joshi, G.D. (1983). Studies on changes in Alphonso mango (Mangifera indica L.) fruits during transport and storage. A. Ph.D. thesis submitted to Indian Agricultural Research Institute, New Delhi.

Kays, S.J., (1999). Pre-harvest factors affecting appearance. Post-harvest Biol. Technol., 15: 233-247.

Lee, L., J. Arul, R. Leneki, and Castaigne (1995). A review on modified atmosphere packaging and preservation of fresh fruits and vegetables: Physiological basis and practical aspects. Part I Packaging Technol. Sci., 8: 315-331.

Lopez, A. C., Ramirez-Bustamante, F., J. B. Jaldez-Torres, and S, R. Rojas-Villegas (2000). Ripening and quality changes in mango fruit as affected by coating with an edible film. International J. Food Quality, 23: 479-486.

Mane, A.V. (2013). Influence of 1methylcyclopropene (1-MCP) on postharvest physiology and physicochemical changes in Alphonso mango (Mangifera indica L.). A Ph.D thesis submitted to UAS, Dharwad.

Masalkar, S. D., R. S. Gaikwad, and J. K. Dhemre (2006). Effect of post harvest treatment on shelf life and quality of Alphonso mango fruits in cool chamber and ambient condition. The Orissa J. Hort., 34(2): 69-73.

Niemann, N., (2005). The effect of 1-MCP, controlled atmosphere and heat treatments on santa tomatoes. Ph.D. Thesis, University of Johannesburg.

Padhye, P.B., (1997). Studies on some aspects of post-harvest handling of mango (Mangifera indica L.) Cv. Alphonso. M.Sc. (Agri.) Thesis submitted to 
Konkan Krishi Vidyapeeth, Dapoli, Dist- Ratnagiri (M.S.).

Pandey, G. and B. P. Singh (2007). Comparative response of 1Methlycyclopropene and $\mathrm{KMnO}_{4}$ on post - harvest behaviour of mango. Indian J. Hort., 64(2): 123-126.

Panse, V. G. and P. V. Sukhatme (1967). Statistical methods for agricultural workers ( $2^{\text {nd }}$ eds) Indian Council of Agricultural Research, New Delhi. Pp. 381.

Rathore, H. A., T. Masud, S. Sammi, and A. H. Soomro (2007). Effect of storage on physico-chemical composition and sensory properties of mango (Mangifera indica L.) variety Dashehari. Pakistan J. Nutr., 6(2): 143- 148.

Singh, V. K. and N. Pathak (2008). Response of 1-Methlcyclopropene on activities of pectin hydrolases and associated postharvest physiological changes in different mango cultivars. Indian $J$. Hort., 65(1): 20-24.

Tefera A., T. Seyoum, K. Woldetsadik (2007). Effect of Disinfection, Packaging, and Storage Environment on the Shelf Life of Mango. Biosystems Engineering, 96(2): 201-212.

Wills, R.B.H., W.B. McGlasson, D. Graham, and D.C. Joyce, (2007). Post-harvest: An introduction to the physiology and handling of fruit, vegetables and ornamentals, $5^{\text {th }}$ edition: CABI, pp. 502508.

Zaharah, S.S. and Z. Singh (2013). Nitric oxide fumigation delays mango fruit ripening. Acta Hort. (ISHS) 992: 543550.

\section{How to cite this article:}

Burondkar, Z.M., C.D. Pawar, P.M. Haldankar, M.M. Burondkar, P.B. Kardile, P.G. Borkar and Dhekale, J.S. 2018. Effect of Packaging and Cushioning Material Used During Road Transportation on Ripening Behavior and Storage of Alphonso Mango Fruits. Int.J.Curr.Microbiol.App.Sci. 7(05): 2667-2677. doi: https://doi.org/10.20546/ijcmas.2018.705.309 